Eur J Clin Chem Clin Biochem

1995; 33:315-322

(c) 1995 Walter de Gruyter \& Co. Berlin. New York

\title{
Evaluation of the Hitachi 911 for Routine Urine Analysis and for Measurement of Various Special Serum Analytes
}

\author{
By Jan P. van Straalen, Anja Leyte, Joop A. Weber, Jozef P. M. C. Gorgels and Gerard T. B. Sanders \\ Laboratorium voor Algemene Klinische Chemie, Academisch Ziekenhuis bij de Universiteit van Amsterdam, \\ Amsterdam. The Netherlands
}

(Received November 11, 1994/February 7, 1995)

Summary: The Boehringer Mannheim Hitachi 911 is a selective analyzer for 35 different methods including 3 ionselective electrode (ISE) methods. We have evaluated this analyzer primarily to obtain objective information on its applicability for routine urine analyses in our laboratory. We also implemented appropriate assays for various special serum- and whole blood-tests, some for the first time on the Hitachi 911 and some with modified settings. Analytical evaluation involved NCCLS EP5-T2 (imprecision), NCCLS EP6-P (linearity), Krouwer 27 (multifactor) and Passing \& Bablok (method comparison) evaluation protocols. With the exception of evidence of systematic erroneous sample predilution, overall results were favourable. Practicability of the Hitachi 911 was judged by simulating daily routine. During a period of two weeks, daily urine samples were rerun on the Hitachi 911 , leading to a gain of about $50 \%$ in total processing time. It was concluded that the Hitachi 911 meets the requirements in terms of analytical performance, reliability, versatility and speed for an analyzer to be used in a routine (urine) setting, while having a distinct role in special (serum/whole blood) measurements.

\section{Introduction}

In our 1000 bed academic hospital a relatively large number of urine analyses are performed daily. In looking for a replacement for our dedicated analyzer for urinalysis, we realized that not many data specifically concerning urine are available as a basis for selection. The choice of a new clinical chemistry analyzer requires the objective assessment of its analytical and practical performance. The former aspect is nowadays evaluated routinely with the use of one or more defined protocols and algorithms. Based on previous experience (1) we have decided to use evaluation protocols developed by the American National Committee for Clinical Laboratory Standards (NCCLS) for this study. Thus, NCCLS EP5T2 (EP5) and EP6-P (EP6) $(2,3)$ are one-at-a-time protocols used for testing imprecision and linearity, respectively. The EP5 protocol provides data on within-run, run-to-run, day-to-day and total imprecision. Linearity according to the EP6 protocol is either present or absent; in the latter case, and for very precise assays (1), quantification of the deviation from linearity is possible with the use of the data generated in the Kroll \& Emancipator algorithm $(4,5)$. The multifactor Krouwer 27 protocol $(6,7)$ provides a simultaneous estimation of various variables, including drift and carry-over. In addition, methods can be compared according to Passing \& Bablok (8), relating the measurement of analytes by new tests and/or analyzers to reference- or standard methods. In the present study, we have used the above protocols and algorithms to evaluate the performance of the Hitachi 911 for assays measuring the following analytes: sodium, potassium, calcium, phosphate, urea, creatinine, glucose and total protein in urine. We also tested determinations of lactate, iron, ferritin, haptoglobin, transferrin, digoxin, vitamin $\mathrm{B}_{12}$ and folate in serum, and cyclosporin in whole blood.

Next to the analytical quality, the practicability performance of an analyzer plays an important role in the medical laboratory. This was evaluated as follows: following the manufacturers' instructions with respect to calibration and control frequency, we gained information on various aspects of daily use of the Hitachi 911 in routine 
practice. For a period of 15 days and extrapolated to one year, all routine urine samples were analyzed both using the present methods and on the Hitachi 911, and turnaround times were compared.

\section{Materials and Methods}

\section{Analyzer}

The Hitachi 911 is a selective access analyzer with a capacity of 35 different tests including 3 ISE methods. Its output rate is 360 tests per hour without ISE and 720 tests per hour with ISE. The ISE unit (indirect method) consists of three flow through electrodes measuring sodium, potassium and chloride. By means of two reagent-arms, one to four reagents can be added to a sample. The optical system contains a halogen lamp, a wave- length grating device and twelve wavelength dependent diodes. The instrument has flexible measuring windows allowing measurements from 3 to 16.5 minutes. The measurement cycle is 20 seconds. All assays are performed at $37^{\circ} \mathrm{C}$. The reagents are kept refrigerated at $10^{\circ} \mathrm{C}$.

\section{Assays}

.1

The Hitachi 911 has so called defined channels for fixed applications (i.e. reagents provided by Boehringer Mannheim (BM)), and open channels which give the user the opportunity to program analytical parameter settings freely. In total, 22 tests were installed during the evaluation period (not all are discussed here) (tab. 1). Urine assays were performed as described by the manufacturers (tab. 1), except for the following cases which involved modifications in the settings defined by BM: calcium, glucose and total protein. For calcium and glucose, this related to the calibration methods used and was intended to improve the linearity and the
Tab. 1 Overview of assays investigated on the Hitachi 911 Suppliers: BM: Boehringer Mannheim; SYVA: Syva diagnostics. Type of analysis: 2: 2 point end; $3: 2$ point rate; 4 : multipoint rate.
Sample volume $\left(1^{*}\right): 11$ times prediluted sample; Sample volume $\left(2^{*}\right): 26$ times prediluted sample.

\begin{tabular}{|c|c|c|c|c|c|c|c|c|c|}
\hline Analyte & $\begin{array}{l}\text { Method } \\
\text { (supplier) }\end{array}$ & $\begin{array}{l}\text { Type } \\
\text { of } \\
\text { analysis }\end{array}$ & $\begin{array}{l}\text { Calibra- } \\
\text { tion } \\
\text { type }\end{array}$ & $\begin{array}{l}\text { Wave- } \\
\text { length } \\
\text { (nm) } \\
\text { (prim./- } \\
\text { sec.) }\end{array}$ & $\begin{array}{l}\text { Sample } \\
\text { volume } \\
(\mu \mathrm{l})\end{array}$ & $\begin{array}{l}\text { Reagent } 1 \\
(\mu \mathrm{l})\end{array}$ & $\begin{array}{l}\text { Reagent } 2 \\
(\mu \mathrm{l})\end{array}$ & $\begin{array}{l}\text { Reagent } 3 \\
(\mu \mathrm{l})\end{array}$ & $\begin{array}{l}\text { Reagent } 4 \\
(\mu \mathrm{l})\end{array}$ \\
\hline $\begin{array}{l}\text { Sodium, } \\
\text { Potassium }\end{array}$ & ISE & & linear & & 20 & 1220 & 600 & - & - \\
\hline Calcium & $\begin{array}{l}\text { Cresolphthalein } \\
\text { (BM) }\end{array}$ & 2 & linear & $340 / 700$ & 10 & 250 & 100 & - & \\
\hline Phosphate & $\begin{array}{l}\text { Molybdate } \\
(\mathrm{BM})\end{array}$ & 2 & linear & $340 / 700$ & $\begin{array}{l}5 \\
\left(1^{*}\right)\end{array}$ & 250 & - & 110 & - \\
\hline Urea & $\begin{array}{l}\text { Urease } \\
\text { (BM) }\end{array}$ & 3 & linear & $340 / 415$ & $\begin{array}{l}4 \\
\left(1^{*}\right)\end{array}$ & 320 & 80 & - & - \\
\hline Creatinine & $\begin{array}{l}\text { Jaffe } \\
\text { (BM) }\end{array}$ & 3 & linear & $505 / 570$ & 2 & 250 & - & 50 & - \\
\hline Glucose & $\begin{array}{l}\text { Hexokinase } \\
(\mathrm{BM})\end{array}$ & 2 & spline & $340 / 415$ & 3 & 250 & 50 & - & - \\
\hline Protein & $\begin{array}{l}\text { Benzothonium-Cl } \\
\text { (BM) }\end{array}$ & 2 & spline & $505 / 700$ & 15 & 250 & - & 100 & 135 \\
\hline Iron & $\begin{array}{l}\text { Ferrozine } \\
(\mathrm{BM})\end{array}$ & 2 & linear & $570 / 700$ & 20 & 250 & - & 50 & - \\
\hline Transferrin & $\begin{array}{l}\text { Tina-quant } \\
(\mathrm{BM})\end{array}$ & 2 & logit-log & $600 / 700$ & 3 & 330 & - & 70 & - \\
\hline Ferritin & $\begin{array}{l}\text { Tina-quant } \\
(\mathrm{BM})\end{array}$ & 2 & $\operatorname{logit}-\log$ & 800 & 10 & 190 & - & 50 & - \\
\hline Cyclosporin & $\begin{array}{l}\text { EMIT } \\
\text { (SYVA) }\end{array}$ & 2 & $\operatorname{logit}-\log$ & $340 / 700$ & 30 & 150 & 70 & - & - \\
\hline Digoxin & $\begin{array}{l}\text { Cedia } \\
\text { (BM) }\end{array}$ & 4 & linear & $570 / 660$ & 18 & 100 & - & 140 & 90 \\
\hline Lactate & $\begin{array}{l}\text { Enzymatic } \\
(\mathrm{BM})\end{array}$ & 2 & linear & $340 / 376$ & 4 & 200 & 50 & 50 & - \\
\hline Haptoglobin & $\begin{array}{l}\text { Immunoturbi- } \\
\text { dimetric }\end{array}$ & 2 & $\operatorname{logit}-\log$ & $340 / 700$ & $\begin{array}{l}4 \\
\left(2^{*}\right)\end{array}$ & 200 & - & 43 & - \\
\hline
\end{tabular}


linear range. In the original BM calcium determination, a 2 point calibration was employed ( 0 and $2.5 \mathrm{mmol} / \mathrm{l})$, whereas our application involved a 5 point calibration $(0,1.25,2.50,3.75$, and $5 \mathrm{mmol} / \mathrm{l}$ ) calculated with linear regression. The BM glucose determination, also with a two point calibration ( 0 and $20 \mathrm{mmol} / \mathrm{l})$, was modified to involve a 5 point calibration $(0,5,10,25$ and 50 $\mathrm{mmol} / \mathrm{l})$ calculated with cubic spline curve fitting. It is important to note that as with patient samples, the calibration samples with a glucose concentration of $25 \mathrm{mmol} / 1$ or higher are automatically prediluted (eight times, $30 \mu \mathrm{l}+210 \mu \mathrm{l}$ ) by the analyzer. The total protein assay was modified with a third reagent (surfactant or Brij $35,100 \mathrm{~g} / 1$ final), to be added just before the cuvette washing step. This reagent prevents contamination of the cuvettes with denaturated proteins. Furthermore, one analyte was measured with dual settings: ferritin, using two different calibration characteristics namely

(a): „lower extended range"-measuring range $0-400 \mu \mathrm{g} / 1$ and $15 \mu \mathrm{l}$ sample volume (Ferritin 1);

(b): „normal range"-measuring range $0-800 \mu \mathrm{g} / \mathrm{l}$ and $5 \mu \mathrm{l}$ sample volume (Ferritin 2).

\section{Calibration}

An aqueous solution with the following composition was used for the calibration of all urine analytes except sodium, potassium and total protein: calcium $2.5 \mathrm{mmol} / \mathrm{h}$, phosphate $25 \mathrm{mmol} / \mathrm{h}$, urea 250 $\mathrm{mmol} / \mathrm{l}$, creatinine $8.75 \mathrm{mmol} / \mathrm{l}$, glucose 5 and $200 \mathrm{mmol} / \mathrm{l}$.

Sodium and potassium were calibrated with the $\mathrm{BM} \mathrm{Na}{ }^{+}, \mathrm{K}^{+}$, $\mathrm{Cl}^{-}$standards.

Total protein was calibrated with Preciset U/CSF Protein (BM).

The following calibration materials were used for the serum tests:

CFAS protein (BM) for transferrin;

Preciset Ferritin (BM) for ferritin;

Orion calibration set (Orion Diagnostica, Espoo, Finland) for haptoglobin.

Digoxin and cyclosporin were calibrated with standards provided by BM (CEDIA digoxin calibrators) and Syva Diagnostica (Syva Diagnostica, San Jose, CA, USA), respectively.

Calibrators included in the CEDIA vitamin $\mathrm{B}_{12}$ and folate test kit (Microgenics Corporation, Concord, USA) were used for these analytes.

Diluted lactic acid calibrator (BM) was used for the calibration of lactate.

$\mathrm{A} \mathrm{Fe}^{2+}$ solution from Baker chemicals (J. T. Baker Inc, USA) was used as a calibrator for the determination of iron.

\section{Imprecision protocol}

Imprecision was tested according to the NCCLS EP5 protocol (2). This protocol involves the measurement of analyte concentrations at two levels, twice per day in duplicate for twenty days, followed by calculation of within-run, between-run, run-tu-run and total imprecision. As sample material various commercial control preparations were used:

Urinorm (Instruchemie, Hilversum, the Netherlands) for the urine analytes;

Bio-Rad (Anaheim, CA, USA) Lyphocheck immunoassay control levels 1,2 and 3 for digoxin, ferritin and $B_{12}$ /folate;

Bio-Rad Liquicheck immunology control (human) levels 1 and 2 for haptoglobin and transferrin;
Bio-Rad Lyphocheck whole blood control (human) levels 1,2 and 3 for cyclosporin;

Precinorm U and Precipath U (BM) for iron;

Precinorm S and Precipath S (BM) for iron and lactate;

Precinorm TDM levels 1,2 and 3 (BM) for digoxin, and

Precinorm $\mathrm{P}$ and Precipath $\mathrm{P}(\mathrm{BM})$ for haptoglobin, transferrin, and ferritin.

Data were checked on outliers. When an outlier exceeded 5.5 times the standard deviation of the test it was removed from the data set (2).

\section{Linearity}

Linearity was tested according the NCCLS EP6 protocol (3). As starting material for the urine analytes we used distilled water ("low") and an aqueous solution with appropriate concentrations of the various analytes ("high"). Two human serum pools were used ("low" and "high"). In some cases (ferritin and digoxin) we had to spike the pooled serum with a stock solution. The spiking method complied with the recommendations of the NCCLS (3). Following the EP6 protocol, mixtures of the low and high pool were made according to the following scheme: low, 3 low +1 high, 2 low +2 high, 1 low +3 high, high. The 5 level mixtures were then tested in two separate runs in quadruplicate. Data were plotted on an $x, y$ linear-linear graph plot and examined visually. In addition, the lack of fit (LOF) of the linear model was determined mathematically with the following algorithms:

$$
\begin{aligned}
& \text { LOF }= \text { RSS }-\mathrm{T}_{\mathrm{E}} \\
& \text { RSS }= \text { Residual sum of squares } \\
& \text { RSS }= {\left[20 \cdot \Sigma\left(\Sigma \mathrm{y}^{2}\right)-(\Sigma \mathrm{y})^{2}\right] / 20-[20 \cdot(\Sigma(\mathrm{x} \cdot \Sigma \mathrm{y}))} \\
&-(4 \cdot \Sigma \mathrm{x}) \cdot(\Sigma \mathrm{y})]^{2} / 20 \cdot\left[80 \cdot \Sigma \mathrm{x}^{2}-(4 \cdot \Sigma \mathrm{x})^{2}\right] \\
& \mathrm{T}_{\mathrm{E}}= \text { Remainder sum of squares } \\
& \mathrm{T}_{\mathrm{E}}=\Sigma\left[\Sigma \mathrm{y}^{2}-(\Sigma \mathrm{y})^{2}\right]
\end{aligned}
$$

Then,

$$
\mathrm{G}=5(\mathrm{LOF}) / \mathrm{T}_{\mathrm{E}}
$$

$G$ was compared with the appropriate critical value of the $F$ distribution. If $G$ was smaller than this critical value, the hypothesis of a linear fit was not rejected. For very precise assays, data with clinically acceptable linearity may be statistically declared non-linear (1). For this reason data from the EP6 observations were also evaluated with the BMD-P5R polynominal regression calculation program (BMDP Statistical Software Inc, USA) in order to obtain $1^{\text {st }}, 2^{\text {nd }}$ and $3^{\text {rd }}$ order polynomes. The $3^{\text {rd }}$ order polynomes were imported in the Kroll \& Emancipator algorithm $(4,5)$ to obtain quantitative measures of relative non-linearity. (Results $<2.5 \%$, from this algorithm, indicate a good linear fit).

\section{Drift and carry-over}

Drift and carry-over were evaluated according to the Krouwer 27 protocol $(6,7)$ with which one can discriminate between linear drift, quadratic drift and concentration dependent drift. In addition, this protocol quantitates the sample related carry-over independently. A further result of the Krouwer 27 protocol provides an estimation of the (non)-linearity and within-run imprecision. In single runs three concentration levels of human serum [low $( \pm 0)$, medium (mixture of low and high) and high (maximum detectable value)] were analyzed nine times in a sequence as prescribed. During the evaluation period the protocol was run in duplicate and the results were interpreted separately.

\section{Method comparison}

The methods investigated on the Hitachi 911 (tab. 1) were compared with those currently in use in our hospital. With the 
exception of sodium and potassium, urine assays were compared with measurements using a continuous flow system (SMA II) from Technicon (Technicon Inc, Tarrytown, New York, USA). The following analytes were measured spectrophotometrically: calcium (cresolphthalein complexing method), phosphate (molybdate UV method), urea (diacetylmonoxime method), creatinine (alkaline pricrate method), and glucose (glucose oxidase-peroxidase method), for more detailed descriptions see 1.c. (9). Sodium and potassium measured on the Hitachi 911 by indirect ISE were compared with flame emission spectrometry (SMA II). Cyclosporin, digoxin and ferritin were compared with the radioimmunoassay methods used in our hospital: cyclosporin was determined with CYCLO-Trac ${ }^{\circledR}$ reagent provided by Incstar (Incstar, Minnesota, USA); reagents for the determination of digoxin and ferritin were obtained from Diagnostic Products Corporation (Diagnostic Products Corporation, Los Angeles, USA). Transferrin and haptoglobin were compared with a nephelometric- and turbidimetric method, respectively. For transferrin we used reagents from Behringwerke (Behringwerke AG, Marburg, Germany) adapted on a Behring nephelometer type 200. The turbidimetric determination of haptoglobin was performed using reagent from Atlantic antibodies (Incstar, Minnesota, USA) adapted on a COBAS BIO analyzer (Hoffmann La Roche, Switzerland). Iron was measured using the same assay on both the Hitachi 911 and the Hitachi 747.

\section{Statistics}

For calculation of imprecision, linearity and Krouwer 27 parameters, we used EVAL-KIT software (CKCHL, Tilburg, the Netherlands). Passing \& Bablok mathematics (8) were used for the calculation of the method comparison parameters.

\section{Practicability performance}

Practicability assessment was performed in the following manner: during a period of 15 working days we reanalysed our daily urine routine samples on the Hitachi 911. All actions were administrated such as number of (re)-calibrations because of reagent change and sample reruns, and in addition turnaround time was assessed.

\section{Results and Discussion}

\section{General}

Results for vitamin $B_{12}$ and folate tests are not included in this paper. Although no proper methodology was available, we nevertheless attempted to implement these assays on the Hitachi 911. However, we did not succeed: within-run coefficients of variation (CVs) were routinely over $15 \%$. This may relate to the fact that the Hitachi 911 does not allow the incubation times of over $15 \mathrm{~min}$ that are recommended by the assay manufacturer. We did not pursue this any further.

\section{Imprecision}

Data for the within-run, run-to-run, day-to-day and the total imprecision for the urine analytes are summarized in table 2. Imprecision data for the serum- and whole blood tests are given in table 3 . It should be noted that the way imprecisions are calculated in this protocol (2) may lead to within-run CVs being larger than day-to-day CVs (e.g. calcium, $2.76 \mathrm{mmol} / \mathrm{l}$ ). For all urine analytes, acceptable CVs were found: total CVs were less than $3.0 \%$, except for total protein $(3.5 \%$ at the low control level). With regard to creatinine, sodium and potassium, these results are in agreement with those found in a recently published multicentre Hitachi 911 evaluation predominantly focussed on serum and plasma analytes (10). Some of the control materials appeared not to be suitable for this kind of imprecision evaluation: for iron in Precinorm $S$ and Precipath $S$ inexplicable shifts in measured levels were noticed, whereas the use of Precinorm $U$ and Precipath $U$ resulted in CVs ranging from 1.1 to $3.2 \%$,
Tab. 2 Imprecision of urine assays performed on the Hitachi 911. Imprecision was quantitated using the NCCLS EP5-T2 protocol (2) as described in Materials and Methods.
RD: creatinine, reduced volume; DL: creatinine, sample predilution.

$\mathrm{CV}$ : coefficient of variation (for calculations, see figure 1).

\begin{tabular}{|c|c|c|c|c|c|}
\hline Analyte & Mean concentration & $\begin{array}{l}\text { Within-run CV } \\
(\%)\end{array}$ & $\begin{array}{l}\text { Run-to-run CV } \\
(\%)\end{array}$ & $\begin{array}{l}\text { Day-to-day CV } \\
(\%)\end{array}$ & $\begin{array}{l}\text { Total CV } \\
(\%)\end{array}$ \\
\hline Sodium & $68.47 \mathrm{mmol} / 1$ & 0.64 & 0.85 & 1.11 & 1.34 \\
\hline Sodium & $134.13 \mathrm{mmol} / \mathrm{l}$ & 0.46 & 0.86 & 0.69 & 0.98 \\
\hline Potassium & $49.95 \mathrm{mmol} / 1$ & 0.56 & 0.80 & 2.00 & 2.12 \\
\hline Potassium & $96.92 \mathrm{mmol} / 1$ & 0.66 & 1.12 & 2.80 & 2.94 \\
\hline Calcium & $1.42 \mathrm{mmol} / \mathrm{l}$ & 1.41 & 1.41 & 1.41 & 1.41 \\
\hline Calcium & $2.76 \mathrm{mmol} / \mathrm{l}$ & 2.54 & 2.17 & 1.44 & 2.90 \\
\hline Phosphorus & $19.68 \mathrm{mmol} / \mathrm{l}$ & 1.78 & 1.37 & 1.37 & 2.13 \\
\hline Phosphorus & $38.81 \mathrm{mmol} / 1$ & 1.42 & 1.21 & 0.98 & 1.65 \\
\hline Urea & $206.17 \mathrm{mmol} / 1$ & 0.90 & 1.32 & 1.17 & 1.63 \\
\hline Urea & $405.44 \mathrm{mmol} / 1$ & 1.24 & 1.06 & 0.85 & 1.43 \\
\hline Creatinine RD & $7.96 \mathrm{mmol} / \mathrm{l}$ & 1.26 & 1.76 & 1.63 & 2.14 \\
\hline Creatinine DL & $15.33 \mathrm{mmol} / \mathrm{l}$ & 1.44 & 1.96 & 1.89 & 2.54 \\
\hline Glucose & $6.89 \mathrm{mmol} / 1$ & 1.31 & 1.45 & 1.02 & 1.74 \\
\hline Glucose & $65.21 \mathrm{mmol} / 1$ & 1.49 & 2.61 & 2.02 & 2.93 \\
\hline Total protein & $0.57 \mathrm{~g} / 1$ & 1.75 & 1.75 & 1.75 & 3.50 \\
\hline Total protein & $2.09 \mathrm{~g} / 1$ & 0.96 & . 1.44 & 2.39 & 2.87 \\
\hline
\end{tabular}


Tab. 3 Imprecision of serum and whole blood assays performed on the Hitachi 911.

Imprecision was quantitated using the NCCLS EP5-T2 protocol (2) as described in Materials and Methods.
Ferritin 1: new set points; Ferritin 2: extended measuring range. $\mathrm{CV}$ : coefficient of variation (for calculations, see figure 1). Information on the controls is provided in Materials and Methods.

\begin{tabular}{|c|c|c|c|c|c|}
\hline Analyte & Mean concentration & $\begin{array}{l}\text { Within-run CV } \\
(\%)\end{array}$ & $\begin{array}{l}\text { Run-to-run CV } \\
(\%)\end{array}$ & $\begin{array}{l}\text { Day-to-day CV } \\
(\%)\end{array}$ & $\begin{array}{l}\text { Total CV } \\
(\%)\end{array}$ \\
\hline Iron Precinorm $\mathrm{S}$ & $10.04 \mu \mathrm{mol} / 1$ & 2.79 & 2.69 & 15.04 & 15.34 \\
\hline Iron Precinorm U & $15.31 \mu \mathrm{mol} / \mathrm{l}$ & 2.09 & 2.35 & 2.29 & 3.20 \\
\hline Iron Precipath $\mathrm{S}$ & $39.16 \mu \mathrm{mol} / 1$ & 1.20 & 3.32 & 25.92 & 26.02 \\
\hline Iron Precipath U & $22.93 \mu \mathrm{mol} / \mathrm{s}$ & 1.31 & 2.44 & 2.53 & 3.18 \\
\hline Lactate Precinorm S & $2.71 \mathrm{mmol} / 1$ & 1.11 & 1.48 & 1.85 & 2.21 \\
\hline Lactate Precipath S & $1.99 \mathrm{mmol} / 1$ & 1.51 & 2.02 & 1.51 & 2.52 \\
\hline Digoxin 370-1 & $0.39 \mu \mathrm{g} / 1$ & 15.38 & 10.26 & 23.08 & 25.64 \\
\hline Digoxin $370-2$ & $1.69 \mu \mathrm{g} / 1$ & 2.96 & 4.14 & 6.51 & 7.69 \\
\hline Digoxin $370-3$ & $3.04 \mu \mathrm{g} / 1$ & 1.97 & 3.29 & 4.28 & 5.26 \\
\hline Digoxin TDM-1 & $0.87 \mu \mathrm{g} / \mathrm{l}$ & 9.22 & 6.92 & 8.07 & 11.53 \\
\hline Digoxin DTM-2 & $1.83 \mu \mathrm{g} / \mathrm{l}$ & 2.74 & 2.19 & 6.02 & 6.57 \\
\hline Digoxin TDM-3 & $3.21 \mu \mathrm{g} / 1$ & 2.18 & 2.18 & 5.30 & 5.61 \\
\hline Ferritin 1 Precinorm $\mathbf{P}$ & $76.28 \mu \mathrm{g} / \mathrm{l}$ & 2.61 & 5.55 & 5.20 & 6.78 \\
\hline Ferritin 1 Precipath $\mathrm{P}$ & $327.37 \mu \mathrm{g} / 1$ & 3.81 & 5.98 & 6.54 & 8.24 \\
\hline Ferritin 2 Precinorm $\mathrm{P}$ & $78.52 \mu \mathrm{g} / 1$ & 1.94 & 4.72 & 4.56 & 5.82 \\
\hline Ferritin 2 Precipath $\mathrm{P}$ & $325.31 \mu \mathrm{g} / 1$ & 1.63 & 2.92 & 5.49 & 5.98 \\
\hline Haptoglobin Precinorm $\mathbf{P}$ & $1.27 \mathrm{~g} / 1$ & 3.16 & 3.16 & 3.16 & 4.73 \\
\hline Haptoglobin Precipath P & $2.22 \mathrm{~g} / \mathrm{l}$ & 1.81 & 4.06 & 4.51 & 5.42 \\
\hline Transferrin Precinorm $\mathrm{P}$ & $3.44 \mu \mathrm{g} / 1$ & 1.75 & 2.33 & 2.04 & 2.91 \\
\hline Transferrin Precipath P & $4.37 \mu \mathrm{g} / \mathrm{l}$ & 2.06 & 2.29 & 1.60 & 2.52 \\
\hline Cyclosporin 561 & $97.57 \mu \mathrm{g} / 1$ & 6.48 & 6.66 & 4.63 & 8.04 \\
\hline Cyclosporin 562 & $261.98 \mu \mathrm{g} / 1$ & 4.44 & 3.27 & 6.42 & 7.51 \\
\hline
\end{tabular}

comparable to previously published findings (10). Furthermore, controls provided by Bio-Rad showed extremely high CVs for ferritin, haptoglobin and transferrin, ranging from 9 to $16 \%$. This is possibly caused by instability of these materials. As an alternative, we measured these analytes in Precinorm $\mathrm{P}$ and Precipath $\mathrm{P}$ for the EP5 protocol; this reduced the variation to 2.5 to $5.5 \%$. For cyclosporin only one set of controls is available: Bio-Rad Lyphochek whole blood control. The rather high CVs for cyclosporin appear to be inherent to this material, since calibrators and patient material performed notably better. However, the EP5 procedure was not repeated with human material.

\section{Linearity}

Table 4 shows the results of the linearity evaluation for those analytes tested. In the specified ranges, all tests except the one for calcium were accepted as linear. For urinary calcium, if measured according to the serum specifications, linearity is lost above $5 \mathrm{mmol} / \mathrm{l}$ (calcium BM). Adaptation of the calcium calibration settings (see Introduction) to a 5 point instead of a two point procedure improved linearity (by visual inspection) up to approximately $9 \mathrm{mmol} / \mathrm{l}$ (calcium AMC) (fig. 1). It should be noted that although the glucose determination was linear up to a theoretical concentration of 200 $\mathrm{mmol} / \mathrm{l}$, the measured values were incorrect (glucose $\mathrm{BM})$. Figure 2 illustrates that for all samples that were prediluted (i.e. with first measurement values higher than $20 \mathrm{mmol} / \mathrm{l})$, final values of glucose concentration were about $20 \%$ lower than expected. Apparently, sample predilution by the Hitachi 911 is characterized by a systematic error. As a pragmatic solution, we have adapted the calibration procedure to include standards with values above $20 \mathrm{mmol} / \mathrm{l}$, therefore requiring predilution, resulting in a correct response in the higher concentration range (glucose AMC) (fig. 2). The success of this problem solving procedure moreover indicates that the dilution error relates to the sample and/or diluent handling by the Hitachi 911 . The error is therefore predicted to cause problems in any assay using sample predilution without calibration predilution.

\section{Drift and carry-over}

Drift and carry-over were tested for the same analytes as in the linearity evaluation (tab. 4), according to the Krouwer 27 protocol $(6,7)$. No significant drift or sample carry-over could be demonstrated with this sensitive protocol (data not shown).

In addition, total protein determination was tested for carry-over between serum and urine samples by using a sample tray intermittently filled with human serum and urine. Even in these extreme circumstances (total protein concentrations varying between 0 and $2.5 \mathrm{~g} / \mathrm{l}$ ), no carryover was established. 
Tab. 4 Linearity.

K \& E: Kroll \& Emancipator relative non-linearity $(4,5)$;
BM: original settings according to Boehringer Mannheim;

AMC: changed settings as described in Materials and Methods.

\begin{tabular}{|c|c|c|c|c|c|}
\hline Analyte & $\begin{array}{l}\mathrm{x} \\
\text { upper limits }\end{array}$ & $\begin{array}{l}\mathbf{x} \\
\text { lower limits }\end{array}$ & $\begin{array}{l}y \\
\text { upper limits }\end{array}$ & $\begin{array}{l}\text { y } \\
\text { lower limits }\end{array}$ & $\begin{array}{l}K \& E \\
(\%)\end{array}$ \\
\hline Sodium & $200.00 \mathrm{mmol} / \mathrm{l}$ & $0.00 \mathrm{mmol} / 1$ & $203.00 \mathrm{mmol} / \mathrm{l}$ & $1.60 \mathrm{mmol} / 1$ & 0.227 \\
\hline Potassium & $200.00 \mathrm{mmol} / 1$ & $0.00 \mathrm{mmol} / \mathrm{l}$ & $200.00 \mathrm{mmol} / 1$ & $0.18 \mathrm{mmol} / 1$ & 0.590 \\
\hline Calcium (BM) & $10.00 \mathrm{mmol} / \mathrm{h}$ & $0.00 \mathrm{mmol} / 1$ & $7.73 \mathrm{mmol} / 1$ & $0.00 \mathrm{mmol} / 1$ & 2.814 \\
\hline Calcium (AMC) & $10.00 \mathrm{mmol} / \mathrm{l}$ & $0.00 \mathrm{mmol} / 1$ & $9.43 \mathrm{mmol} / \mathrm{l}$ & $0.00 \mathrm{mmol} / \mathrm{h}^{\prime}$ & 0.484 \\
\hline Phosphate & $50.00 \mathrm{mmol} / \mathrm{h}$ & $0.00 \mathrm{mmol} / 1$ & $49.60 \mathrm{mmol} / 1$ & $0.00 \mathrm{mmol} / \mathrm{l}$ & 0.052 \\
\hline Urea & $500.00 \mathrm{mmol} / 1$ & $0.00 \mathrm{mmol} / 1$ & $516.00 \mathrm{mmol} / 1$ & $0.00 \mathrm{mmol} / \mathrm{l}$ & 0.066 \\
\hline Creatinine & $25.00 \mathrm{mmol} / 1$ & $0.00 \mathrm{mmol} / 1$ & $24.18 \mathrm{mmol} / 1$ & $0.00 \mathrm{mmol} / \mathrm{l}$ & 0.396 \\
\hline Protein & $3.00 \mathrm{~g} / 1$ & $0.00 \mathrm{~g} / 1$ & $2.99 \mathrm{~g} / \mathrm{l}$ & $0.00 \mathrm{~g} / 1$ & 0.492 \\
\hline Glucose (BM) & $200.00 \mathrm{mmol} / 1$ & $0.00 \mathrm{mmol} / 1$ & $178.00 \mathrm{mmol} / 1$ & $0.00 \mathrm{~g} / \mathrm{l}$ & 0.131 \\
\hline Glucose (AMC) & $200.00 \mathrm{mmol} / 1$ & $0.00 \mathrm{mmol} / 1$ & $200.00 \mathrm{mmol} / 1$ & $0.00 \mathrm{mmol} / 1$ & 1.152 \\
\hline Iron & $216.50 \mu \mathrm{mol} / 1$ & $3.83 \mu \mathrm{mol} / 1$ & $208.70 \mu \mathrm{mol} / \mathrm{l}$ & $2.84 \mu \mathrm{mol} / \mathrm{l}$ & 0.383 \\
\hline Ferritin (1) & $319.00 \mu \mathrm{g} / 1$ & $12.30 \mu \mathrm{g} / 1$ & $406.63 \mu \mathrm{g} / 1$ & $12.27 \mu \mathrm{g} / 1$ & 1.052 \\
\hline Ferritin (2) & $611.00 \mu \mathrm{g} / 1$ & $12.30 \mu \mathrm{g} / 1$ & $933.40 \mu \mathrm{g} / 1$ & $12.66 \mu \mathrm{g} / 1$ & 0.743 \\
\hline Digoxin & $4.07 \mu \mathrm{g} / 1$ & $0.14 \mu \mathrm{g} / \mathrm{l}$ & $4.09 \mu \mathrm{g} / 1$ & $0.19 \mu \mathrm{g} / 1$ & 1.287 \\
\hline
\end{tabular}

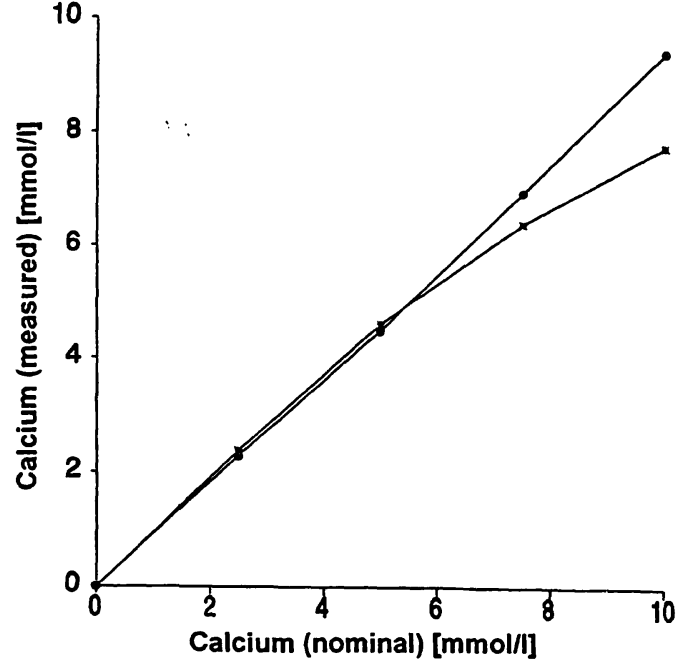

Fig. 1 Improved linearity of modified calcium assay.

Five calcium level mixtures were prepared as prescribed for linearity evaluation according to the NCCLS EP6 protocol (3), and calcium was measured using either the original BM settings (*; two point calibration) or the modified settings ( $\boldsymbol{O}$; five point calibration) as described in Materials and Methods.

\section{Method comparison}

The results of the method comparisons according to Passing \& Bablok (8) are combined in table 5 including the measured ranges. For each method, samples were equally divided over the measuring range. In general, correlations between measurements on the Hitachi 911 and measurements with the currently used methods were acceptable. An optimal correlation was found for sodium and potassium measured with the Hitachi 911 ISE in comparison with a flame emission spectrometer. The glucose determinations correlated

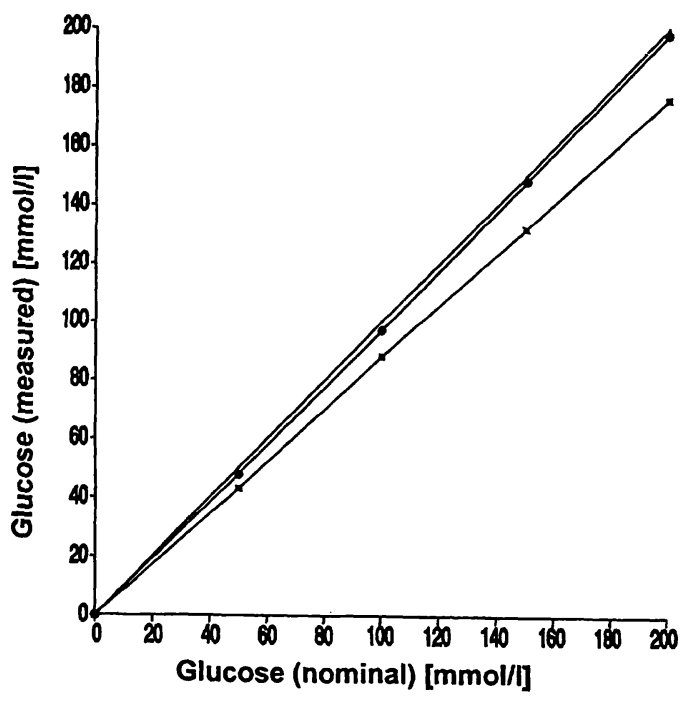

Fig. 2 Sample predilution error.

Five glucose level mixtures were prepared as prescribed for linearity evaluation according to the NCCLS EP6 protocol (3). Glucose was measured (involving sample predilution if [glucose] higher than $20 \mathrm{mmol} / \mathrm{l}$ ) using a two point calibration without calibrator glucose concentrations above $20 \mathrm{mmol} / \mathrm{l}$ and therefore without calibrator predilution (*), and using a five point calibration with calibrator glucose concentrations above $20 \mathrm{mmol} / \mathrm{l}(\bullet) .(\cdot)$ : nominal [glucose $]=$ measured [glucose $]$.

poorly in the lower section of the measuring range caused by the incapability of the SMA II to discriminate glucose values between $0-5 \mathrm{mmol} / \mathrm{l}$. Data in this concentration range were not included in the statistical evaluation.

\section{Assessment of practibility}

Practicability evaluation related to the performance of the analyzer in daily routine use. This was investigated as follows: complying with the recommendations of the 
Tab. 5 Method comparison for analytes measured on the Hitachi 911 and with reference or standard methods.

Method comparison was performed according to Passing \& Bablok

(8) as described in Materials and Methods. $n$ : number of samples;
Syx: standard error of estimated y; r: coefficient of correlation; (U): urine; Ferritin (1): new set points; Ferritin (2): extended measuring range.

\begin{tabular}{|c|c|c|c|c|c|c|c|}
\hline \multirow{2}{*}{$\frac{\text { Analyte }}{\text { Sodium (U) }}$} & \multirow{2}{*}{$\begin{array}{l}\text { Compared with } \\
\text { SMA }\end{array}$} & \multirow{2}{*}{$\frac{\mathrm{n}}{119}$} & \multicolumn{2}{|c|}{ Range } & \multirow{2}{*}{$\begin{array}{l}\text { Linear regression } \\
y=0.997 x+1.001\end{array}$} & \multirow{2}{*}{$\frac{S_{y x}}{2.90}$} & \multirow{2}{*}{$\frac{r}{0.999}$} \\
\hline & & & 1 & $-240 \mathrm{mmol} / 1$ & & & \\
\hline Potassium (U) & SMA & 119 & 1 & $-130 \mathrm{mmol} /$ & $y=1.032 x+0.803$ & 1.16 & 0.999 \\
\hline Calcium (U) & SMA & 55 & 1 & $9 \mathrm{mmol} / 1$ & $y=0.953 x-0.043$ & 0.11 & 0.998 \\
\hline Phosphate (U) & SMA & 119 & 1 & - $\quad 50 \mathrm{mmol} / \mathrm{l}$ & $y=1.028 x-0.803$ & 1.41 & 0.993 \\
\hline Urea (U) & SMA & 119 & 50 & - $500 \mathrm{mmol} / \mathrm{l}$ & $y=1.058 x+0.460$ & 11.88 & 0.996 \\
\hline Creatinine (U) & SMA & 118 & 0.7 & $-22 \mathrm{mmol} / \mathrm{l}$ & $y=0.989 x-0.079$ & 0.41 & 0.996 \\
\hline Protein $(U)$ & Protein Analyzer & 108 & 0.1 & $7.5 \mathrm{~g} / 1$ & $y=0.945 x-0.053$ & 0.17 & 0.992 \\
\hline Glucose (U) & SMA & 43 & 5.0 & $-219 \mathrm{mmol} / \mathrm{l}$ & $y=0.966 x-0.771$ & 2.10 & 0.998 \\
\hline Ferritin (1) & RIA & 98 & 4 & $-4500 \mu \mathrm{g} / 1$ & $y=0.939 x-4.636$ & 101.69 & 0.989 \\
\hline Ferritin (1) & RIA & 79 & 4 & $-450 \mu \mathrm{g} / 1$ & $y=0.915 x-4.028$ & 47.51 & 0.867 \\
\hline Ferritin (2) & RIA & 98 & 4 & $-4500 \mu \mathrm{g} / 1$ & $y=1.046 x-4.785$ & 95.56 & 0.992 \\
\hline Ferritin (2) & RIA & 79 & 4 & $-450 \mu \mathrm{g} / 1$ & $y=1.039 x-4.879$ & 65.24 & 0.827 \\
\hline Ferritin (1) & Ferritin (2) & 99 & 4 & $-4500 \mu \mathrm{g} / 1$ & $y=1.128 x+1.280$ & 50.86 & 0.998 \\
\hline Ferritin (1) & Ferritin (2) & 78 & 4 & $-450 \mu \mathrm{g} / 1$ & $y=1.154 x+0.298$ & 10.80 & 0.993 \\
\hline Transferrin & Nephelometry & 99 & 0.7 & $-\quad 5.0 \mathrm{~g} / 1$ & $y=0.867 x+0.047$ & 0.18 & 0.970 \\
\hline Iron & Hitachi 747 & 100 & 1 & $-70 \mu \mathrm{mol} / 1$ & $y=0.987 x-0.312$ & 1.20 & 0.990 \\
\hline Cyclosporin & RIA & 59 & 55 & $-300 \mu \mathrm{g} / 1$ & $y=0.886 x+5.867$ & 14.94 & 0.964 \\
\hline Digoxin & RIA & 75 & 0.5 & $-\quad 3 \mu \mathrm{g} / \mathrm{l}$ & $y=1.063 x-0.098$ & 0.23 & 0.953 \\
\hline Haptoglobin & Cobas Bio & 89 & 0.03 & $5 \mathrm{~g} / 1$ & $y=1.130 x-0.240$ & 0.18 & 0.843 \\
\hline
\end{tabular}

test- and analyzer manufacturer with respect to calibration frequencies and reagent stability (calibration was every 24 hours and upon reagent renewal; controls were included in every run with an interval of 30 samples), all clinical requests for routine urine analyses were reanalyzed on the Hitachi 911 for a period of 15 working days. A daily average of $23(\mathrm{SD}=13)$ patient urine samples with $3(\mathrm{SD}=3)$ test requests each were processed. Data obtained on the reagents, calibrators and controls used were extrapolated to a one-year period using the total amount of test requests from 1993 (see Materials and Methods). It was noted that for some tests (e. g. total protein) the daily requests are less than the samples necessary for calibration and control. As a result, the costs of these tests are strongly influenced by the relatively numerous calibrations. The turnaround time for the daily routine load of urine samples was two hours, meaning a considerable shorter analyzer occupancy than in our present laboratory setting with the SMA II requiring four hours. Clearly, this leaves enough room for the use of the Hitachi 911 in measurements of various special serum and whole blood analytes, as intended.

\section{Overall conclusion}

From the results presented it can be deduced that notwithstanding its problems with sample predilution, the Hitachi 911 is a good alternative to the SMA II for routine urine chemistry. With appropriate precision, all measurements including total protein can be made from a single tube. The analyzer has enough speed and versatility to combine its use in urinalysis with the acceptable performance of several homogeneous immunoassays and other measurements of special serum or whole blood analytes.

\section{Acknowledgements}

We thank $C$. E. A. Lauret for valuable practical assistance during the evaluation experiments and Dr. W. Stockmann for his helpful comments on the manuscript.

\section{References}

1. Vreken P, Dols JLS, Weber JA, Gorgels JPMC, Sanders GTB. Analytische evaluatie van de BM/Hitachi 747: ervaringen met evaluatieprotocollen. Tijdschr NVKC 1994; 19:47-55.

2. Kennedy JW, Carey RN, Coolen RB, Garber CC, Hartmann $\mathrm{AE}$, Lee $\mathrm{HT}$, et al. Evaluation of precision performance of clinical chemistry devices. NCCLS document EP5-T2. Villanova PA, National Committee for Clinical Laboratory Standards, 1992.

3. Passey RB, Bee DE, Caffo A, Erikson JM. Evaluation of the linearity of quantative analytical methods; proposed guideline.

NCCLS document EP6-P. Villanova PA, National Committee for Clinical Laboratory Standards, 1986.

4. Kroll MH, Emancipator KA. Theoretical evaluation of linearity. Clin Chem 1993; 39:405-13.

5. Emancipator KA, Kroll MH. A quantitative measure of nonlinearity. Clin Chem 1993; 39:766-72.

6. Krouwer JS. Multi factor designs IV. How multi factor designs improve the estimate of total error by accounting for protocolspecific biases. Clin Chem 1991; 37:26-9. 
7. Krouwer JS, Stewart WN, Schlain B. A multi factor experimental design for evaluating random-access analyzers. Clin Chem 1988; 34:1894-6.

8. Passing $\mathrm{H}$, Bablok W. A new biometrical procedure for testing the equality of measurements from two different analytical methods. Application of linear regression procedures for method comparison studies in clinical chemistry, part I. J Clin Chem Clin Biochem 1983; 21:709-20.

9. Tietz NW, Burtis CA, Ashwood ER, editors. Textbook of Clinical Chemistry, 2nd edn. WB Saunders Company, Philadelphia, 1994.
10. Zaman Z, Blackaert N, Cobbaert Ch, Gillery P, Hagemann P, Luthe $\mathrm{H}$, et al. Multicentre evaluation of the Boehringer Mannheim/Hitachi 911 analysis system. J Autom Chem 1993; 15:189-208.

J. P. van Straalen Department of Clinical Chemistry Academic Medical Centre F1-217.1, Meibergdreef 9 NL-1105 AZ Amsterdam . The Netherlands 